PRODUCTION

ENGINEERING ARCHIVES
2014, Vol. 2, No. 1, pp 9-11

ISSN 2553-5156 (print version)

ISSN 2353-7779 (online version)

\title{
Visual inspection as one of the important elements of the quality control
}

\author{
Pawel Szklarzyk ${ }^{1}$ \\ ${ }^{1}$ Czestochowa University of Technology, Institute of Production Engineering, Armii Krajowej 19B, 42-200 Częstochowa
}

\begin{abstract}
Quality control of the production process allows to detect incompatibilities. One of the key elements of quality control is a visual inspection. The object of the research is to determine the essential elements having an impact on visual inspections. Research was carried out according to the BOST method designed at the Institute of Production Engineering, Technical University of Czestochowa.
\end{abstract}

Key words - maximally 6 terms (10 font)

\section{Introduction}

Platon described a quality as: "A certain degree of perfection" (HAMrol A. MANTURA A. 2004). Perfection will probably never be reached but at all costs to be sought. Application of between operational quality control eliminates incompatibility products during production, resulting in a reduction of the production costs as well as costs associated with the service, replacement, repair of the product and loss of customer trust.

\section{Presentation of the company}

The research facility is a group formed in 1973 and has focused its activities on AUTOMOTIV industries. The research facility specializes in automotive safety systems (seat belts, airbags, etc.). Other sectors of production research facility are: air conditioning systems, ventilation systems, industrial ventilation systems, information technology, sanitary and the production of household appliances. The company exports its products except for Spain, also to Poland,
Germany, Italy, Czech Republic, Turkey, Austria, Portugal, Argentina, Brazil, USA, China, Japan and Hungary. Relationships with clients based on three pillars: service, confidentiality and professional obligations. Thanks to the high quality technology company ranks among the top European companies. In Figure 1 is showed a schematic of the knife edge die to the production of belt hooks.

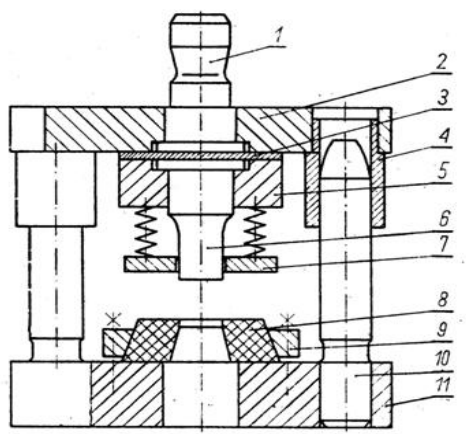

Fig. 1. The knife-edge die: 1- die shank, 2- head block, 3- back-up plate, 4- pilot, 5- punch plate, 6- plunger die,

7- striper, 8-die block, 9- pressure ring, 10- guide post, 11- die block.

Source: SIŃCZAK JAN 2001 


\section{Research methodology}

The method BOST (the name comes from the first two letters of the author's names) is legally protected (BORKOWSKI S. 2012a) Toyota management principles are described characteristic factors. Their number depends on he scope of the rule, ranging from 4 to 10 . A set of agents is called areas. Respondents in the right pane to assess the validity of the factor by inserting one of the numbers within the limits of the scale (BORKOWSKI S. 2012c).

The $7^{\text {th }}$ principle of the Toyota management is as follow (BORKOWSKI S. 2012b, BORKOWSKI S. 2013):

\section{hidden.}

Principle 7. Use visual control so no problems are

The $7^{\text {th }}$ Toyota management principle, BOST survey describes question about the E7 area (BORKOWSKI S., RoSAK - SZYROCKA J., SZKLARZYK P. 2011):

\section{What is the most important element in the visual in- spection?}

In the box type 1, 2, 3, 4, 5, 6 (6 factor the most important).

\begin{tabular}{|c|c|}
\hline CS & Cleanliness, tidiness \\
\hline EP & Flow \\
\hline TI & Information board \\
\hline $\mathbf{U P}$ & Participation in the places of production \\
\hline ME & Monitoring \\
\hline GW & Graphical presentation of results \\
\hline
\end{tabular}

The results of the survey are presented in a Table 1.

Table 1 Principle 7. Evaluation structure [\%] of the factors' importance for $E 7$ area. Concerns the automotive industry

\begin{tabular}{|c|c|c|c|c|c|c|}
\hline \multirow{2}{*}{$\begin{array}{c}\text { Evalu- } \\
\text { ation }\end{array}$} & \multicolumn{7}{|c|}{ Indicating the factors } \\
\cline { 2 - 7 } & CS & EP & TI & UP & ME & GW \\
\hline 1 & 5 & 15 & 25 & 10 & 20 & 25 \\
\hline 2 & 0 & 45 & 10 & 10 & 30 & 5 \\
\hline 3 & 10 & 5 & 15 & 15 & 35 & 20 \\
\hline 4 & 25 & 10 & 20 & 10 & 5 & 30 \\
\hline 5 & 15 & 20 & 15 & 35 & 5 & 10 \\
\hline 6 & 45 & 5 & 15 & 20 & 5 & 10 \\
\hline
\end{tabular}

Source: own study

\section{The validity of factors describing the $7^{\text {th }}$ principle of the Toyota manage- ment}

The $2^{\text {nd }}$ Figure is presented Pareto - Lorenz diagrams described in paper (BORKOWSKI S. 2004). Pareto - Lorenz diagrams was used for the validity construction of factors of area E7.

Based on the description of the $\mathrm{x}$-axis Figure 2, the ranks of the validity of the factors analyzed area has the form:

- For evaluation ,1".

$(\mathrm{GW} ; \mathrm{TI})>\mathrm{ME}>\mathrm{EP}>\mathrm{UP}>\mathrm{CS}$

- For evaluation ,2".

$\mathrm{EP}>\mathrm{ME}>$ (TI; UP) $>\mathrm{GW}>\mathrm{CS}$

- For evaluation ,3”.

$\mathrm{ME}>\mathrm{GW}>(\mathrm{TI} ; \mathrm{UP})>\mathrm{CS}>\mathrm{EP}$

- For evaluation „4”.

$\mathrm{GW}>\mathrm{CS}>\mathrm{TI}>(\mathrm{EP} ; \mathrm{UP})>\mathrm{ME}$

- For evaluation ,5".

$$
\mathrm{UP}>\mathrm{EP}>(\mathrm{CS} ; \mathrm{TI})>\mathrm{GW}>\mathrm{ME}
$$

- For evaluation ,6".

$$
\mathrm{CS}>\mathrm{UP}>\mathrm{TI}>\mathrm{GW}>(\mathrm{EP} ; \mathrm{ME})
$$

Figure 2a and the Formula 1, has been presented range of validity of factors for evaluate " $1 "$. Based on the data found that the most ratings of "1" received the factors information board (TI) and graphical presentation of results (GW). Rating of "1" states $25 \%$.

Figure $2 \mathrm{~b}$ and the Formula 2, has been presented range of validity of factors for evaluate "2". Based on the data found that the most ratings of "2" received the factor flow (EP). Rating of "2" states $45 \%$ of total ratings for factor flow (EP). The factor cleanliness, tidiness (EP) has not received the evaluation " 2 ".

Figure 2c and the Formula 3, has been presented range of validity of factors for evaluate " 3 ". Based on the data found, that the most ratings of " 3 " received the factor monitoring (ME). Rating of "3" states 35\% of total ratings for factor monitoring (ME).

Figure 2d and the Formula 4, has been presented range of validity of factors for evaluate "4". Based on the data found, that the most ratings of " 4 " received the factor graphical presentation of results (GW). Rating of "4" states $30 \%$ of total ratings.

Figure $2 \mathrm{e}$ and the Formula 5, has been presented range of validity of factors for evaluate " 5 ". Based on the data found, that the most ratings of " 5 " received the factor participation in the places of production (UP). Rating of " 5 " states $30 \%$ of total ratings for factor participation in the places of production (UP). 

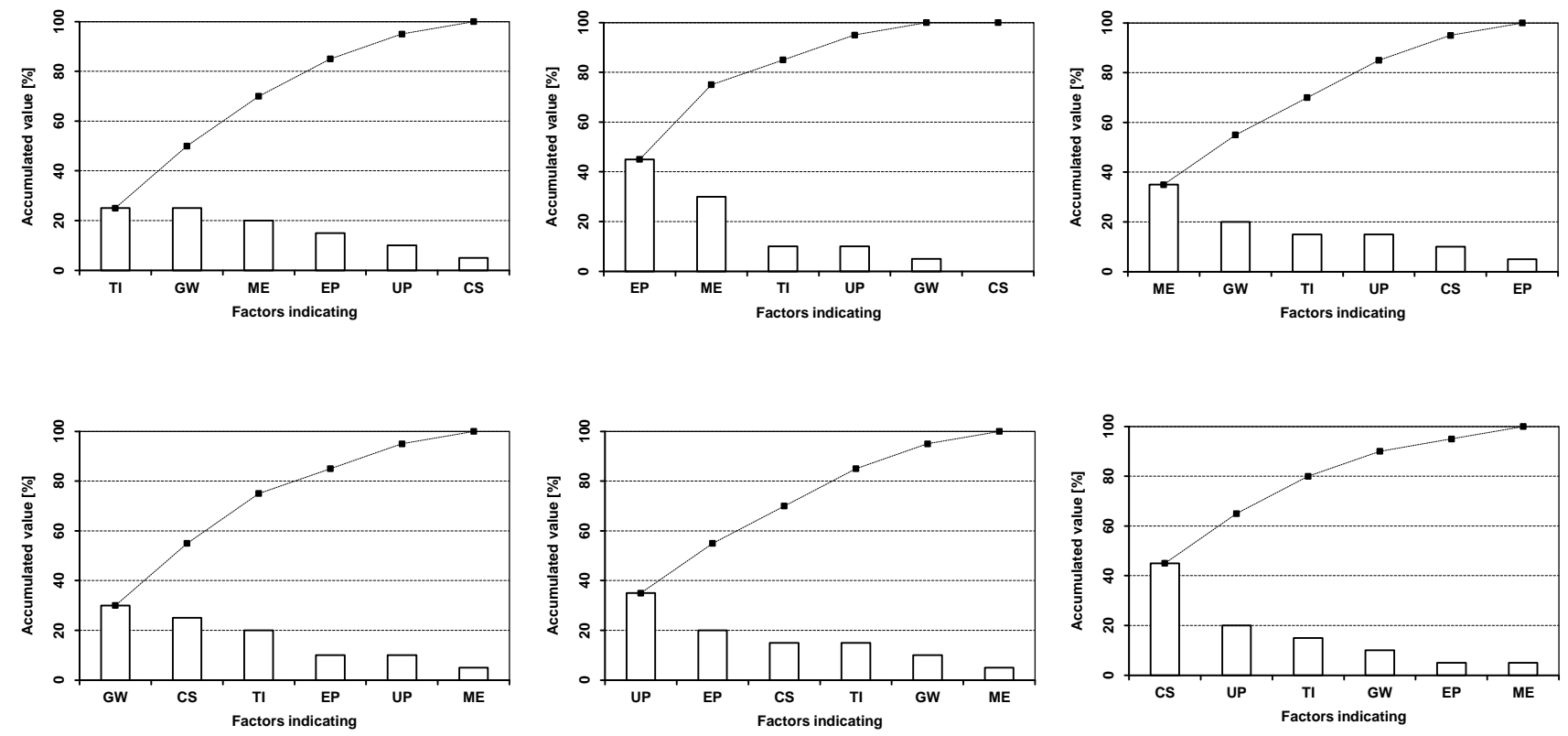

Fig. 2. E7. Principle 7. Pareto-Lorenz diagrams of the factors' importance E7 area for evaluations: a) ,,1", b),,2", c) ,,3", d) ,4, e) ,5", f) ,,6”. Concerns the automotive industry.

Source: own study

Figure $2 \mathrm{f}$ and the Formula 6 , has been presented range of validity of factors for evaluate " 6 ". Based on the data found, that the most ratings of "6" received the factor cleanliness, tidiness (CS). Rating of "6" states $45 \%$ of total ratings for factor cleanliness, tidiness (CS).

\section{Conclusion}

In the paper was presented the BOST method and the results of research carried out in Automotive industry.By analyzing average values we obtain a chain of factors, which presents the following Formula (7).

$$
\mathrm{CS}>\mathrm{UP}>\mathrm{TI}>\mathrm{GW}>\mathrm{EP}>\mathrm{ME}
$$

After analyzing the resulting chain, it was found that the element which is the most important for employees in the visual inspection is a factor: cleanliness, tidiness (CS). Takes it the first place in a number of validity. In second place in terms of importance is a factor: Participation in the places of production (UP). As the least important factor in the quality of visual inspection, the respondents recognized factor: monitoring (ME). The results allow to assess the awareness of employees about the importance of visual inspection.
The results are an indication for the employer on company improvements in this area.

\section{References}

1. BORKOWSKI S. 2004. Measuring the level of quality. Wyższa Szkoła Zarządzania i Marketingu in Sosnowiec. Sosnowiec.

2. BORKOWSKI S. 2012a. Documents containing coined the term (TOYOTARYZM) and containing the name and structure of the developed method (BOST). Confirmation of the date. "AAK" PATENT OFFICE s.c. Częstochowa.

3. BORKOWSKI S. 2012b. Toyota's management principles in questions. The results of BOST method. PTM. Warszawa.

4. BORKOWSKI S. 2012c. Toyotaryzm. The results of BOST method. PTM. Warszawa.

5. BORKOWSKI S. 2013. Toyotarity. Term, model, range. Production Engineering Archives 1, pp 2-5.

6. BORKOWSKI S., ROSAK - SZYROCKA J., SZKLARZYK P. 2011. Control of the steel constructionof halls. Chapter 6. Toyotarity. Control in organizations. Borkowski S., Czajkowska A. (ed.) Yurii V. Makovetsky. Dnipropetrovs'k.

7. Hamrol A. Mantura A. 2004. Quality management. Theory and practice. Wyd. Naukowe PWN. Warszawa.

8. SIŃCZAK J. 2001. Plastic working processes - laboratory. Akademia Górniczo - Hutnicza, Kraków. 